九州大学学術情報リポジトリ

Kyushu University Institutional Repository

\title{
Oryzalin-induced Allotetraploids of and Intersubgeneric Hybrid between Evergreen and Deciduous Azaleas
}

\section{Sakai, Kaori}

Laboratory of Horticultural Science, Division of Agricultural Botany, Department of Plant Resources, Graduate School of Bioresource and Bioenvironmental Sciences, Kyushu University

Miyajima, Ikuo

Crop Production Section, Institute of Tropical Agriculture, Kyushu University

Ureshino, Kenji

Laboratory of Olericultural and Floricultural Science, Faculty of Agriculture, Iwate University

Ozaki, Yukio

Laboratory of Agricultural Ecology, Division of Agricultural Ecology, Department of Plant

Resources, Faculty of Agriculture, Kyushu University

他

https://doi.org/10.5109/4589

出版情報：九州大学大学院農学研究院紀要. 49 (2)，pp. 293-299，2004-10-01. Faculty of Agriculture, Kyushu University

バージョン :

権利関係: 
J. Fac. Agr., Kyushu Univ., 49 (2), 293-299 (2004)

\title{
Oryzalin-induced Allotetraploids of an Intersubgeneric Hybrid between Evergreen and Deciduous Azaleas
}

\author{
Kaori SAKAI ${ }^{*}$, Ikuo MIYAJIMA², Kenji URESHINO ${ }^{3}$, \\ Yukio OZAKI ${ }^{4}$ and Hiroshi OKUBO \\ Laboratory of Horticultural Science, Division of Agricultural Botany, \\ Department of Plant Resources, Faculty of Agriculture, \\ Kyushu University, Fukuoka 812-8581, Japan \\ (Received June 30, 2004 and accepted July 13, 2004)
}

\begin{abstract}
Pollen viability of intersubgeneric hybrids between evergreen and deciduous azaleas was much lower than that of their parents. No capsule set in the crossings with the hybrids when used either as seed or pollen parents. In vitro chromosome doubling with oryzalin was attempted for restoring the fertility of the hybrid. Survival rates of the explants were more than $50 \%$ in oryzalin treatments, though high concentration and long term treatments brought the survival rates and number of shoots per explant low, under which number of shoots per explant also decreased. Twenty tetraploid and 28 mixoploid $(2 x+4 x)$ plants were obtained by the treatments from 123 individuals. The most suitable conditions for obtaining tetraploids appeared to be $0.01 \%$ oryzalin treatment for 48 hours.
\end{abstract}

\section{INTRODUCTION}

Evergreen azaleas have been grown as garden trees and potted plants for hundreds of years in Japan because of their beautiful flower colors and evergreen leaves. There are many evergreen azalea species growing wild in Kyushu Island, Japan, from which several hundred varieties such as Kurume Azaleas and Hirado Azaleas have been bred. Their flower colors have been, however, restricted to white, pink, red, reddish-purple and purple, and yellow-flowered cultivars have not yet been obtained.

Numbers of breeders have tried to produce yellow-flowered evergreen azaleas using intersubgeneric crossings between evergreen species and yellow-flowered deciduous species such as Rhododendron japonicum f. flavum Suringer or $R$. molle G. Don (Akabane et al., 1971; Heursel, 1981; Yamaguchi et al., 1985). Most of these crossings, however, failed to obtain progenies because of low frequency of capsule set and viable seeds. Almost of the progenies from the crossings, if obtained, were albino or pale-green plants, which withered away within one year (Heursel, 1981; Yamaguchi, 1986). Akabane (1993) obtained intersubgeneric hybrids from the crosses between white-flowered

1 Laboratory of Horticultural Science, Division of Agricultural Botany, Department of Plant Resources, Graduate School of Bioresource and Bioenvironmental Sciences, Kyushu University

2 Crop Production Section, Institute of Tropical Agriculture, Kyushu University

${ }^{3}$ Laboratory of Olericultural and Floricultural Science, Faculty of Agriculture, Iwate University, Morioka 020-8550, Japan

${ }^{4}$ Laboratory of Agricultural Ecology, Division of Agricultural Ecology, Department of Plant Resources, Faculty of Agriculture, Kyushu University, Fukuoka 811-2307, Japan

* Corresponding author (k_sakai@agr.kyushu-u.ac.jp) 
evergreen azalea and yellow-flowered $R$. japonicum f. flavum. Flowers of the hybrids were pale yellow at full bloom stage, and the carotenoid pigment, the main agent of the deep yellow flower color of $R$. japonicum f. flavum, was detected in the petals of the hybrids (Miyajima et al., 2000). Thus, these hybrids may be favorable breeding materials for yellow-flowered evergreen azalea cultivars.

The sterility of distant hybrids is common phenomenon, and it may be considered as the results of the genetic unbalance. In such sterility caused from chromosomal structural differences, doubling of chromosomes, particularly in somatic tissue, results in normal meiosis of complete homologous chromosomes.

Flow cytometry has been established for rapid and efficient estimation of ploidy levels in some crops (Van Tuyl et al., 1992; Tosca et al., 1995; Ozaki et al., 1998). Ploidy analysis by flow cytometry has been also accepted in Rhododendron (Vainola, 2000; De Schepper et al., 2001; Ureshino and Miyajima, 1998, Sakai et al., 2003).

The objective of this study is to assess the gametic fertility of intersubgeneric hybrids and to establish the methods for obtaining allotetraploid azaleas through in vitro oryzalin treatment.

\section{MATERIALS AND METHODS}

\section{Pollen fertility of intersubgeneric hybrids}

Pollen fertility of evergreen azalea (E), R. japonicum f. flavum (D) and their intersubgeneric hybrids (E X D) was examined (Table 1). Pollen grains were collected at their full bloom stage, and observed with an optical microscope after staining with aceto-carmine for 10 minutes. The pollen grains were classified to perfect pollen with densely stained cytoplasm or to empty pollen that was not stained. More than 400 pollen grains in three replications were observed in each accession.

Table 1. Evergreen and deciduous azaleas and their hybrids used as cross parents in this study.

\begin{tabular}{|c|c|c|}
\hline Parents & Code & Description \\
\hline $\begin{array}{l}\text { Evergreen azalea } \\
(R . \text { kiusianum X } R \text {. eriocarpum })(\text { No. } 1,2)^{2}\end{array}$ & $\mathrm{E} 1,2$ & $\begin{array}{l}\text { White-flowered interspecific hybrid, } \\
\text { subgen. Tsutsusi X subgen. Tsutsusi }\end{array}$ \\
\hline $\begin{array}{l}\text { Deciduous azalea } \\
R . \text { japonicum f. flavum }(\text { No. } 1,2)\end{array}$ & $\mathrm{D} 1,2$ & $\begin{array}{l}\text { Yellow-flowered species, } \\
\text { subgen. Pentanthera }\end{array}$ \\
\hline $\begin{array}{l}\text { Hybrid } \\
((R . \text { kiusianum X R. eriocarpum) (No. } 2) \\
\quad \text { X R. japonicum f. flavum (No. 2)) (No. } 1,2)\end{array}$ & (E2 X D2) 1,2 & $\begin{array}{l}\text { Pale yellow-flowered } \\
\text { intersubgeneric hybrid }\end{array}$ \\
\hline
\end{tabular}

${ }^{2}(\mathrm{)})$ individual number

\section{Induction of multiple shoots}

The artificial crossings between evergreen azalea (E) and $R$. japonicum f. flavum (D) were carried out on May 1997. The obtained seeds were sown in October 1997 on Anderson's rhododendron medium (Anderson, 1984) supplemented with $50 \mathrm{mgl}^{-1}$ of gib- 
berellic acid ( $\mathrm{pH} 5.0)$. After seed germination, green and vigorous seedlings were transplanted on the Anderson's rhododendron medium with $10 \mathrm{mgl}^{-1}$ of $\mathrm{N}^{6}-(2$-isopentenyl) adenine (2ip) to induce multiple shoots. The multiplicated shoots from one seedling were cut into segments and supplied for in vitro oryzalin treatments after confirming their hybridity (Ureshino et al., 1998).

\section{In vitro oryzalin treatments}

The autoclaved nutrient solution (Anderson's rhododendron medium with $10 \mathrm{mgl}^{-1} 2 \mathrm{ip}$ and $3 \%$ sucrose) with $\mathrm{pH} 5.0$ was supplemented with filter-sterilized $0,0.001,0.005$ or $0.01 \%$ oryzalin dissolved in $1 \%$ DMSO (dimethyl sulfoxide) after being dispensed into $200 \mathrm{ml}$ plastic vessels. Three segments obtained from the multiple shoots were incubated in the light at $25^{\circ} \mathrm{C}$ for 24,48 or 72 hours in the vessels. After the treatment, the segments were washed with distilled water three times. Then the shoots of the segments were cut into $8-10 \mathrm{~mm}$ length, and cultured for five months on the multiplication medium in the light at $25^{\circ} \mathrm{C}$. The shoots obtained from the explants were transferred to the sphagnum in plastic pots, and incubated in the light at $25^{\circ} \mathrm{C}$. The rooted plants were placed to a greenhouse.

\section{Ploidy levels in the regenerated plants}

The assessment of ploidy levels was done by flow cytometry. Young leaves of the generated plants were chopped with a sharp razor blade in nuclei extraction buffer (High resolution DNA kit, Partec), and the suspension containing released nuclei was passed through a $50 \mu \mathrm{m}$ filter. Then, the nuclei in filtrate were stained with four times volume of staining solution (High resolution DNA kit, Partec) containing 4'-6-diamidino-2-phenylindole (DAPI). After shaking the solution gently, samples were analyzed with a flow cytometer (PA Ploidy Analyzer, Partec). Relative DNA content was estimated according to the prominent peak in each measurement.

\section{RESULTS}

Pollen fertility of evergreen azalea (E) and R. japonicum f. flavum (D) was high (79.5-87.4\%), whereas that of their hybrids (E X D) was quite low (0.1-0.6\%) (Table 2). No capsule set when the hybrids were used either as seed or pollen parents in the crossings with evergreen azalea and $R$. japonicum f. flavum (Table 3).

Table 2. Pollen fertility of evergreen and deciduous azaleas and their hybrids.

\begin{tabular}{lc}
\hline Parents & Pollen fertility $^{2}(\%)$ \\
\hline Evergreen azalea & \\
$\quad$ E2 & $79.5 \pm 4.5$ \\
Deciduous azalea & \\
D2 & $87.4 \pm 2.8$ \\
Hybrid & \\
(E2 X D2) 1 & $0.6 \pm 0.2$ \\
(E2 X D2) 2 & $0.1 \pm 0.1$ \\
\hline
\end{tabular}

${ }^{2}$ Mean \pm SE 
The survival rates of the explants were more than $50 \%$ in each treatment with oryzalin though high concentration and long term treatments brought low survival rates and decreased the number of shoots per explant (Table 4).

Diploid and tetraploid plants were easily identified by the flow cytometric analysis as reported by Sakai et al. (2003), i.e., fluorescent intensities at prominent peaks in diploids and tetraploids were about 100 and 200, respectively (Fig. 1). The treated plants, representeing two peaks of fluorescent intensities 100 and 200, were judged to be mixoploids

Table 3. Frequency of capsule set in the crosses with intersubgeneric azalea hybrids.

\begin{tabular}{lc}
\hline Cross & Capsule set $^{z}$ \\
\hline Hybrid x evergreen azalea & \\
(E2 X D2) 1 X E1 & $0 / 5^{y}$ \\
(E2 X D2) 2 X E1 & $0 / 3$ \\
\hline Evergreen azalea X hybrid & $0 / 4$ \\
E1 X (E2 X D2) 1 & $0 / 2$ \\
E1 X (E2 X D2) 2 & $0 / 2$ \\
E2 X (E2 X D2) 1 & $0 / 4$ \\
E2 X (E2 X D2) 2 & \\
Deciduous azalea X hybrid & $0 / 3$ \\
D1 X (E2 X D2) 1 & $0 / 5$ \\
D1 X (E2 X D2) 2 & \\
- Hybrid X hybrid & $0 / 3$ \\
(E2 X D2) 1 X (E2 X D2) 2
\end{tabular}

${ }^{2}$ Capsule sets were observed 3 months after crossing

${ }^{y}$ No. of capsules / No. of pollinated flowers

Table 4. Effects of oryzalin treatments on the survival rates and shoot formation in the intersubgeneric azalea hybrid.

\begin{tabular}{ccccc}
\hline $\begin{array}{c}\text { Concentration } \\
(\%)\end{array}$ & $\begin{array}{c}\text { Duration } \\
\text { (hours) }\end{array}$ & $\begin{array}{c}\text { No. of explants } \\
\text { treated }\end{array}$ & $\begin{array}{c}\text { Survival rate } \\
\text { (\%) }\end{array}$ & $\begin{array}{c}\text { No. of shoots / } \\
\text { explant }\end{array}$ \\
\hline 0 & 24 & 17 & 100 & 9.5 \\
& 48 & 21 & 95.2 & 20.0 \\
0.001 & 72 & 21 & 100 & 18.6 \\
& 24 & 20 & 90.0 & 39.4 \\
0.005 & 48 & 21 & 95.7 & 15.7 \\
& 72 & 18 & 94.0 & 28.5 \\
& 24 & 21 & 71.4 & 31.0 \\
0.01 & 48 & 21 & 76.2 & 35.8 \\
& 72 & 21 & 80.1 & 13.3 \\
& 24 & 21 & 100 & 33.2 \\
& 48 & 21 & 52.4 & 11.3 \\
& 72 & 21 & 62.0 & 11.6 \\
\hline
\end{tabular}

z Data were collected after 5 months of culture 
$(2 \mathrm{x}+4 \mathrm{x})$. In total 123 plants investigated, controls with DMSO maintained the diploid status, and 20 tetraploids and 28 mixoploid plants were obtained (Table 5). The most suitable condition for inducing tetraploid plants was the treatment with $0.01 \%$ oryzalin for 48 hours.

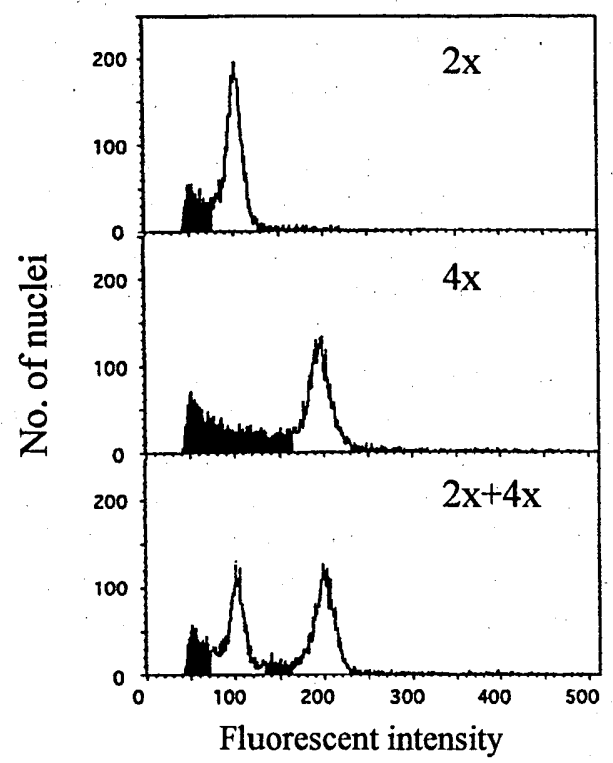

Fig. 1. Flow cytometric histograms of diploid, tetraploid and mixoploid $(2 x+4 x)$ obtained from the in vitro oryzalin treatments for the intersubgeneric azalea hybrid.

Table 5. Effects of oryzalin treatments on the rate of tetraploid induction in the intersubgeneric azalea hybrid.

\begin{tabular}{|c|c|c|c|c|c|}
\hline \multirow{2}{*}{$\begin{array}{c}\text { Concentration } \\
\text { (\%) }\end{array}$} & \multirow{2}{*}{$\begin{array}{l}\text { Duration } \\
\text { (hours) }\end{array}$} & \multirow{2}{*}{$\begin{array}{l}\text { No. of individuals } \\
\text { examined }\end{array}$} & \multicolumn{3}{|c|}{ Ploidy levels (\%) } \\
\hline & & & $2 \mathrm{x}$ & $2 x+4 x$ & $4 \mathrm{x}$ \\
\hline \multirow[t]{3}{*}{0} & 24 & 5 & $5(100)$ & $0(0)$ & $0(0)$ \\
\hline & 48 & 1 & $1(100)$ & $0(0)$ & $0(0)$ \\
\hline & 72 & 9 & $9(100)$ & $0(0)$ & $0(0)$ \\
\hline \multirow[t]{3}{*}{0.001} & 24 & 12 & $10(83.3)$ & $2(16.7)$ & $0(0)$ \\
\hline & 48 & 13 & $6(46.2)$ & $3(23.1)$ & $4(30.8)$ \\
\hline & 72 & 11 & $6(54.5)$ & $4(36.4)$ & $1(9.1)$ \\
\hline \multirow[t]{3}{*}{0.005} & 24 & 12 & $1(8.3)$ & $11(91.7)$ & $0(0)$ \\
\hline & 48 & 11 & $11(100)$ & $0(0)$ & $0(0)$ \\
\hline & 72 & 9 & $8(88.9)$ & $1(11.1)$ & $0(0)$ \\
\hline \multirow[t]{3}{*}{0.01} & 24 & 12 & $12(100)$ & $0(0)$ & $0(0)$ \\
\hline & 48 & 13 & $2(15.4)$ & $0(0)$ & $11(84.6)$ \\
\hline & 72 & 15 & $4(26.7)$ & $7(46.7)$ & $4(26.7)$ \\
\hline Tota & & 123 & $75(61.0)$ & $28(22.8)$ & $20(16.3)$ \\
\hline
\end{tabular}




\section{DISCUSSION}

The hybrid (E X D) of evergreen azalea (E) X R. japonicum f. flavum (D) used in this study may not be used in further breeding. The sterility in hybrids derived from distant hybridization has been considered to be a result of the genetic unbalance as has been found in this study and also reported in many plants such as Lilium (Asano, 1982) and Solanum (Ali et al., 1992). In such cases, chromosome doubling is effective for restoring fertility of the hybrids.

Pryor and Frazier (1968) obtained the colchicine-induced tetraploid azaleas with great potential of improving flower size and petal texture. Although colchicine has been successfully used to induce polyploidy in many horticultural crops, oryzalin is considered superior to colchicine because of its lower phytotoxicity and the absence of long term effects (Tosca et al., 1995).

There are many reports that flow cytometry is a useful method for ploidy level determination and this technique is as a practical and rapid tool for confirming the ploidy levels of plants (Baird et al., 1994; O'Brien et al., 1996; Ozaki et al., 1998; Pinheiro et al., 2000). It was also recognized that the effectiveness of flow cytometry for the ploidy determination of rhododendron hybrids (Vainola, 2000; Sakai et al., 2003). In our study, the in vitro oryzalin treatments of multiple shoots in an intersubgeneric azalea hybrid were proved to be effective for inducing polyploids, and the tetraploid plants, which are predicted to be fertile, was obtained.

Stomata, pollen and roots originate from histogenic layers LI, LII and LIII, respectively (Dermen, 1947; Dermen and Stewart, 1973; Ramulu et al., 1976). The plants, determined to be tetraploid by flow cytometry, had larger guard cells than diploid plants (data not shown). The in vitro oryzalin treatments in this study induced 28 mixoploid plants. Chromosome doubling in LII layer would be confirmed. If the LII of the plants are tetraploid, the regaining of fertility of these chimeric plants is hopeful like tetraploid plants.

\section{ACKNOWLEDGEMENT}

The authors wish to thank Mr. Masaru Akabane for his donation of the white-flowered evergreen azalea. We also thank to Associate Professor Dr. Koichiro Gyokusen in the Laboratry of Silviculture, Faculty of Agriculture, Kyushu University for cooperation in flow cytometric analysis.

\section{REFERENCES}

Akabane, M. 1993 On the cross compatibility $F_{1}$-plants (Rhododendron kiusianum Mak. X R. indicum Sweet) X R. japonicum Suringar. J. Japan. Soc. Hort. Sci., 62 (Suppl. 1): 344-345 (in Japanese)

Akabane, M., A. Yamanaka, D. Takashima, T. Nakatsue and Y. Nakamura 1971 On the fertility of interspecific crossing and the growth of $\mathrm{F}_{1}$ seedlings in rhododendron species. Bull. Tochigi Pref. Agri. Expt. Stn., 15: 95-102 (in Japanese)

Ali, M., H. Okubo and K. Fujieda 1992 Production and characterization of Solanum amphidiploids and their resistance to bacterial wilt. Scientia Hortic. , 49: 181-196

Anderson, W. C. 1984 A revised tissue culture medium for shoot multiplication of rhododedndron. J. Amer. Soc. Hort. Sci., 109: 343-347 
Asano, Y. 1982 Overcoming interspecific hybrid sterility in Lilium. J. Japan. Soc. Hort. Sci., 51: 75-81

Baird, W. V., A. S. Estager and J. K. Wells 1994 Estimating nuclear DNA content in peach and related diploid species using laser flow cytometry and DNA hybridization. J. Amer. Soc. Hort. Sci., 119: 1312-1316

Dermen, H. 1947 Periclinal cytochimeras and histogenesis in cranberry. Amr. J. Bot., 34: 32-43

Dermen, H. and R. N. Stewart 1973 Ontogenic study of floral organs of peach (Prunus persica) utilizing cytochimeral plants. Amr. J. Bot., 60: 283-291

De Schepper, S., L. Leus, M. Mertens, E. Van Bockstaele and M. De Loose 2001 Flow cytometric analysis of ploidy in Rhododendron (subgenus Tsutsusi). HortScience, 36: 125-127

Heursel, J. 1981 Diversity of flower colors in Rhododendron simsii Planch. and prospects for breeding. Euphytica, 30: 9-14

Miyajima, I., K. Ureshino, N. Kobayashi and M. Akabane 2000 Flower color and pigments of intersubgeneric hybrid between white-flowered evergreen and yellow-flowered deciduous azaleas. $J$. Japan. Soc. Hort. Sci., 69: 280-282

O’Brien, I. E. W., D. R. Smith, R. C. Gardner and B. G. Murray 1996 Flow cytometric determination of genome size in Pinus. Plant Sci., 115: 91-99

Ozaki, Y., K. Narikiyo, M. Hiramatsu, K. Ureshino and H. Okubo 1998 Application of flow cytometry for rapid determination of ploidy levels in asparagus (Asparagus officinalis L.). J. Fac. Agr., Kyushu Univ., 43: 83-88

Pinheiro, A. A., M. T. Pozzobon, C. B. do Valle, M. I. O. Penteado and V. T. C. Carneiro 2000 Duplication of the chromosome number of diploid Brachiaria brizantha plants using colchicine. Plant Cell Rep., 19: 274-278

Pryor, R. L. and L. C. Frazier 1968 Colchicine-induced tetraploid azaleas. HortScience, 3: 283-286

Ramulu, K. S., M. Devreux, G. Ancora and U. Laneri 1976 Chimerism in Lycopresicum peruvianum plants regenerated from in vitro cultures of anthers and stem internodes. Z. Pflanzenzüchtg., 76: 299-319

Sakai, K., Y. Ozaki and H. Okubo 2003 Intra- and inter-ploid cross compatibility among diploid triploid and tetraploid Satsuki azaleas. J. Japan. Soc. Hort. Sci., 72 (Suppl. 2): 205 (in Japanese)

Tosca, A., R. Pandlfi, S. Citterio, A. Fasoli and S. Sgorbati 1995 Determination by flow cytometry of the chromosome doubling capacity of colchicine and oryzalin in gynogenetic haploids of Gerbera. Plant Cell Rep., 14: 455-458

Ureshino, K. and I. Miyajima 1998 The relationship between appearance of albino seedlings and their ploidy level in intersectional crossings among azalea species (tentatively translated into English by $\mathrm{K}$. Sakai. from the original Japanese title). J. Japan. Soc. Hort. Sci., 67 (Suppl. 2): 389 (in Japanese)

Ureshino, K., I. Miyajima and M. Akabane 1998 Effectiveness of three-way crossing for the breeding of yellow-flowered evergreen azalea. Euphytica, 104: 113-118

Vainola, A. 2000 Polyploidization and early screening of Rhododendron hybrids. Euphytica, 112: 239-244

Van Tuyl, J. M., B. Meijer and M. P. Dien 1992 The use of oryzalin as an alternative for colchicine in in-vitro chromosome doubling of Lilium and Nerine. Acta Hortic., 325: 625-630

Yamaguchi, S. 1986 In-vitro culture of remote hybrid seedlings aiming to breed new yellow flowered evergreen azalea. Plant Cell Incompatibility Newslett., 18: 50-51

Yamaguchi, S., M. Kunishige and T. Tamura 1985 Interspecific compatibility in Japanese rhododendrons. Bull. Veg. and Omam. Crop Res. Stn. Japan, Ser. B, 8: 87-97 (in Japanese with English summary) 